\title{
LMS-Enabled Blended Learning Use Intentions among Distance Education Tutors: Examining the Mediation Role of Attitude Based on Technology-Related Stimulus-Response Theoretical Framework
}

\author{
Brandford Bervell \\ University of Cape Coast, Cape Coast, College of Distance Education, Maths, Science \& ICT, Ghana \\ ORCID: 0000-0002-3925-6877 \\ Paul Nyagorme \\ University of Cape Coast, Cape Coast, College of Distance Education, Maths, Science \& ICT, Ghana \\ ORCID: 0000-0002-8941-7413 \\ Valentina Arkorful \\ University of Cape Coast, Cape Coast, College of Distance Education, Maths, Science \& ICT, Ghana \\ ORCID: 0000-0001-6658-3067
}

Received: 11 Mar 2020

Accepted: 21 Apr 2020

\begin{abstract}
Distance education delivery has shifted from the mere meaning of distance due to the use of abridged technologies. Current distance education utilizes technologies that have made the term distance a metaphor. The affordances of technology have promoted student-student interaction; teacher-student interaction as well as student-student interaction across boundaries. This has been possible due to blended leaning that combines both the online component in addition to the face-to-face sessions. One of the technologies that have made blended learning possible in distance education is the Learning Management System (LMS). However, intentions towards the use of LMS have been a crucial element in contemporary literature especially in Africa. Consequently, one of the key determinants of LMS use intentions is attitude towards the technology. Hence, this study is focused on unraveling the key determinants of attitude based on a Technology-Related Stimulus-Response Theoretical Framework (TRSR-TF) while addressing empirically, the mediating role of attitude on these determinants. In view of this, the study employed a survey design with the questionnaire as an instrument for data collection from a sample of 267 course tutors in distance education. The results from a Partial Least Squares Structural Equation Modelling (PLS-SEM) approach revealed performance expectancy, effort expectancy and facilitating conditions as key antecedents of attitude towards LMS for blended learning. Again, attitude had a significant mediating effect on all three antecedents in determining behavioural intention towards LMS use for blended learning in distance education. The results of the study suggests that factors such as performance expectancy, effort expectancy and facilitating conditions should be critically addressed while implementing LMS-enabled blended learning because the former factors have a direct effect on attitude towards use intentions of blended learning for distance education delivery.
\end{abstract}

Keywords: distance education, LMS, blended learning, use intention, attitude, determinants

\section{INTRODUCTION}

The emergence of ubiquitous technologies has altered the delivery of distance education (Bervell \& Arkorful, 2020). In this vein, current distance education delivery cannot be without modern technologies (Ntumy- 
Coleman, 2011 cited in Bervell \& Arkorful 2020). According to Moore and Kearsley (2004) definition, distance education is the "teaching and planned learning in which teaching normally occurs in a different place from learning, requiring communication through technologies as well as special institutional organization" (p. 2). Technologies have defined the nature of distance education over the years (Aoki, 2012; Bervell \& Arkorful, 2020; Siemens, Gašević, \& Dawson, 2015). From print-based mail correspondence through tele and video conferencing to web 2.0 technologies, the distance education phenomenon has progressed through three to four generation (Anderson \& Dron, 2011; Aoki, 2012; Siemens, Gašević, \& Dawson, 2015). Consequently, these technologies have rather made easier the organization and management of distance education or improved the entire administration of distance education delivery across the globe. These technologies, for example the web 2.0 and its associated internet-based technologies have provided remedies to the earlier constraints of distance education. These comprised lack of interaction (student-student; student-teacher; teacher-teacher; and content-content) while improving upon student-content interactions that beset the earlier forms of distance education. Contemporary technologies have bridged all the above forms of interaction promoting satisfaction and engagement in distance education (Bervell, Umar, \& Kamilin, 2019; Kuo, Walker, Belland, \& Schroder, 2013; Moore, 2014; Zimmerman, 2012).

A dominant online technology that has made interactions possible in distance education is the Learning Management System (LMS) (Bervell \& Arkorful, 2020; Mohamedbhai, 2011). This technology according to Sharma and Vatta (2013) is a server-based or cloud-based software programme containing information about users, course and content which provides a place to learn and teach without depending on the time and space boundaries" (p. 1). LMS is also distance learning systems that are synchronous, open-network structures created to facilitate active, authentic, creative, collaborative (social), productive and constructive learning while containing electronic tools including email, files, a discussion board, a grade book, an announcement board, assessment tools and multimedia tools (video, RSS feed, audio file, etc) (Bervell, Umar, \& Kamilin, 2019; Deperlioglu, Sarpkaya, \& Ergun, 2011; Tu, Sujo-Montes, Yen, Chan, \& Blocher, 2012). LMS has not only provided forms and levels of interactions in distance education, but has also promoted immediacy of feedback to students on their performance in assessments and also made available students course materials accessible everywhere (Bervell \& Umar, 2018; Bervell, Umar, \& Kamilin, 2019). These affordances of LMS have made most higher education institutions offering distance education to adopt the blended mode which combines both the face-to-face and online aspects of andragogical practices (Bervell \& Arkorful, 2020; Bervell, Umar, \& Kamilin, 2019). Accordingly, there is a growth in the number of universities willing and offering courses for hybrid or blended (a combination of online and face-to- face) learning (Burns, 2011; Horvat, Dobrota, Krsmanovic, \& Cudanov, 2015) across the globe.

However, the implementation of LMS in distance higher education has not been wholly smooth and successful albeit the benefits that this technology brings into blended distance higher education delivery (Bervell \& Umar, 2018; Hastie, Hung, Chen, \& Kinshuk; 2010; Sun, Tsai, Finger, Chen, \& Yeh, 2008). Contemporary researches have revealed some challenges involved in the utilization of LMS-enabled blended learning on the part of instructors in higher education. Factors such as easiness towards use, facilitating conditions towards usage, performance expectations for usage, attitude towards usage, voluntariness of usage, internet accessibility, system quality, social influence, training etc. (Alharbi \& Drew, 2014; Aljaloud 2012; Bervell \& Arkorful, 2020; Bervell \& Umar, 2018; Bousbahi \& Alrazgan, 2015; Chen \& Huang, 2012; Essel \& Owusu-Boateng, 2011; Ghazal, Umar, Aldowah, \& Bervell, 2018; Tu, Sujo-Montes, Yen, Chan, \& Blocher, 2012) etc. have been cited as challenges or barriers. However, most research identify attitude towards technology as a key variable in determining intentions towards LMS technology usage which later culminates into actual usage (Bervell \& Umar, 2018; Kohnke, Cole, \& Bush, 2014; Mtebe, Mbwilo, \& Kissaka, 2016; Mbengo, 2014) etc. Attitude has been defined as a favourable or unfavourable disposition towards an object, individual or situation (Asiri et al., 2012; Fisbein \& Ajzen, 1975). In the technology milieu, the variable can be defined as the behavioural disposition (favourable or unfavourable) of an individual towards the use of a particular technology for job performance (Bervell \& Umar, 2018). Based on the above definition, attitude towards LMS can be explained as tutors' favourable or unfavourable disposition towards the use of LMS for blended learning in distance education. According to Bervell and Umar (2018) tutors' attitudes whether positive or negative, influence their intention behaviours towards LMS for their andragogical endeavours in 
distance education. This means if tutors form positive dispositions towards LMS, their intention behaviours towards the technology for blended learning will be favourable and vice versa. Subsequently, attitude cannot be a standalone factor. Its formation is triggered by either technological dimension factors, societal dimension factors or environmental dimension factors. Within the literature, major technological dimension factors include performance expectancy and effort expectancy; while societal dimension factors are represented by social influence and environmental dimension factors cover facilitating conditions (Davis, 1987; Venkatesh et al., 2003; Venkatesh \& Bala, 2008).

The focus of this paper is to examine the effects of the tripartite dimensional factors on the use of LMS technology on attitude towards LMS for blended learning in distance education. This has become necessary based on the inconsistencies in the literature between the role of attitude within the Technology Acceptance Model (TAM) and the Unified Theory of Acceptance and Use of Technology (UTAUT). While TAM views the effect of attitude on behavioural intention as important and defined by the tripartite effects of ease of use (effort expectancy); usefulness (performance expectancy); social norm (social influence) and facilitating conditions, the UTAUT model proponents propose a spurious effect of the attitude factor in technology uptake. This leaves a gap of inconsistency in the literature. Consequently, this study fills this chasm by way of a direct effect of attitude on behavioural intention towards LMS for blended learning while assessing the effects of the tripartite factors in technology use on attitude towards LMS. Additionally, it seeks to assess a mediation effect of attitude on the tripartite factors in technology use towards behavioural intention of LMS uptake in distance education delivery based on a Partial Least Squares Structural Equation Modelling technique. However, these relationships can best be defined using the Technology-Related StimulusResponse Theoretical Framework (TR-SR-TF) proposed by Bervell \& Umar (2018). The theoretical framework explains that the nature of technology use factors influences individuals' emotional response which leads to an intent behaviour towards a particular technology. Hence, the nature of technology use factors represents the stimuli that trigger an emotional response or reaction representing an individuals' disposition (attitude) towards an intent behaviour exhibition of either avoidance or acceptance towards a particular technology. As a result, if the stimuli trigger a positive emotional response of attitude, the resultant behaviour intent will be an acceptance of the technology (LMS). This is illustrated by Figure 1.

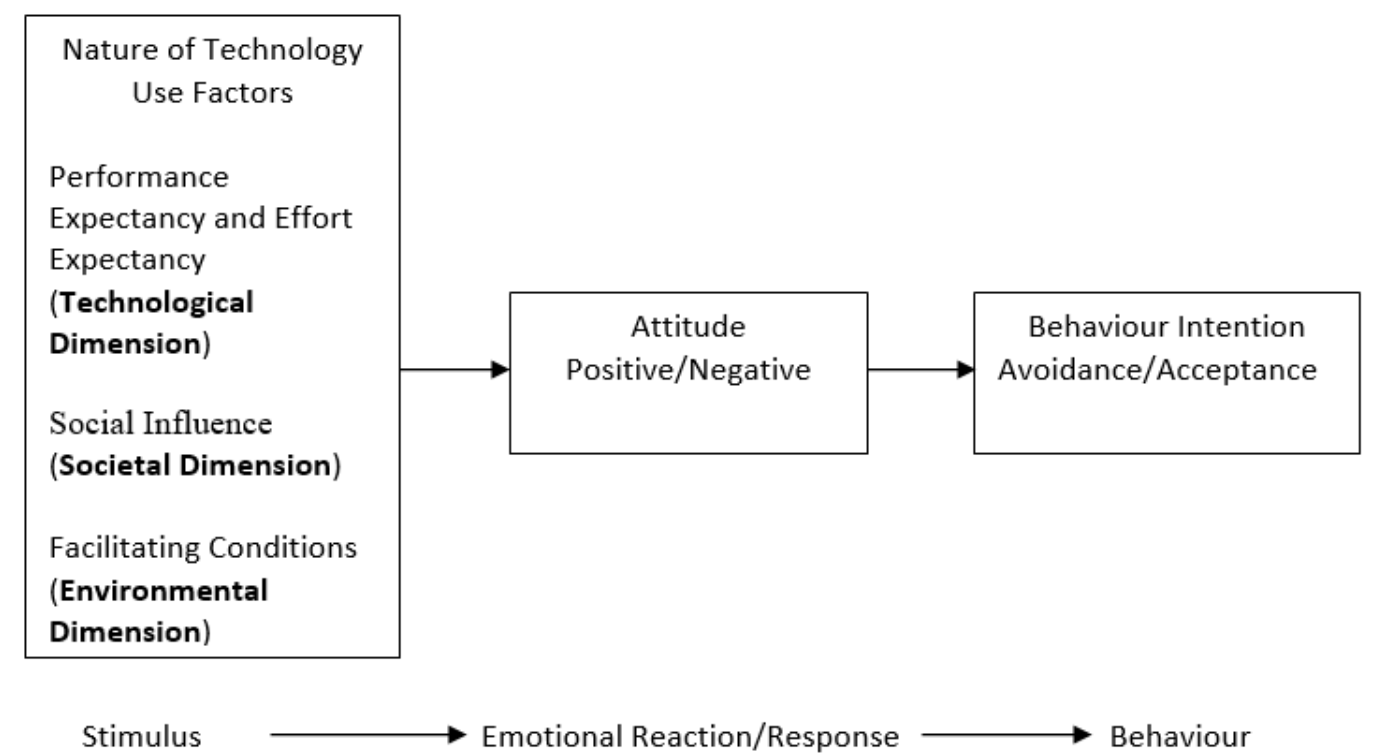

Figure 1. Technology-Related Stimulus-Response Theoretical Framework (TR-SR-TF) Modified from Bervell and Umar (2018)

Against this background, the study is guided by the following research questions:

1. What are the direct effects of performance expectancy and effort expectancy; social influence and facilitating conditions on tutors' attitude towards LMS-enabled blended learning for distance education delivery? 
2. What are the mediation effects of tutors' attitude on performance expectancy and effort expectancy; social influence and facilitating conditions towards tutors' behavioural intention of LMS-enabled blended learning for distance education delivery?

\section{TOWARDS MODEL DEVELOPMENT AND HYPOTHESES FORMULATION}

\section{Relationship between Performance Expectancy and Attitude towards LMS for Blended Learning}

The construct Performance Expectancy is represented in other technology acceptance models as Perceived usefulness (TAM/TAM 2/C-TAM-TPB, TAM3), Extrinsic motivation (MM), Job fit (MPCU), Relative advantage (IDT) and Outcome expectancy (SCT) (Bervell \& Umar, 2017; Venkatesh et al., 2003). This construct defines the degree to which an individual believes that using a system will enable him or her attain gains in job performance (Venkatesh et al., 2003, 2012). In this study, performance expectancy connotes the believe course tutors have, that using the new LMS will enhance their delivery of blended learning in distance teaching and learning. The construct explains that prior to the acceptance of any new technology, individuals project a weighting of the intended benefits to be gained in the event of using that technology with respect to job performance or personal improvement towards discharging responsibilities (Davis, 1981; Venkatesh et al., 2012). Individuals perceive or forecast these intended gains before making a final decision to accept the advocated technology. The higher the expectation of use gains of a particular technology, the more eager a potential adopter will intend to accept and use it (Bervell \& Umar, 2017; Venkatesh et al., 2003). If course tutors view the use of LMS for blended learning as effective, then this will favourably affect their attitude towards LMS. Thus positive view of LMS-enabled blended learning will induce a positive affective feeling towards the technology for blended learning purposes. Hence, performance expectancy has a positive relationship with attitude towards behavioural intention to accept LMS technology. This relationship was earlier verified in the TAM model (Davis, 1987) and later by authors such as Altanopoulou and Tselios (2017), Isaias, Reis, Coutinho, and Lencastre (2017), Nassuora (2012), and Thomas et al. (2013). Against this backdrop, this study proposes that:

H1: Course tutors' performance expectancy of LMS technology has a positive relationship with their attitude towards LMS-enabled blended learning in distance education.

\section{Relationship between Effort Expectancy and Attitude towards LMS for Blended Learning}

Effort expectancy is captioned in other technology acceptance models as Perceived Ease of Use (TAM/TAM2/TAM3), Complexity (MPCU) and Ease of Use (IDT) (Bervell \& Umar, 2017; Venkatesh et al., 2003). The construct Effort Expectancy in UTAUT defines the degree of ease associated with the use of a system (Venkatesh et al., 2003; Venkatesh \& 2012). In this study, it is the degree to which course tutors believe that LMS will be easier to use for blended learning in their distance education instructional delivery. Similar to performance expectancy, effort expectancy has also proven significant across all other technology acceptance models, under both mandatory and voluntary conditions (Venkatesh et al., 2003). The introduction of any new technology arouses the perception of potential users on how easy or otherwise the application of the said system will be in the event of usage in real work context (Venkatesh, 2012). Potential users, mostly used to previous ways and experience of executing tasks over a considerable period of time, have been able to develop antidotes to existing challenges (Bervell \& Umar, 2017). The introduction of a new technology will warrant new adjustment strategies and hence their emphasis on ease of use or otherwise. In this regard, the effect of effort expectancy on acceptance of new technology will be stronger at the initial stage of its introduction (Venkatesh, 2012). Course tutors expectations with regards to the effort needed to utilize LMS for blended learning has an effect on their attitude towards LMS-enabled blended learning. If LMS is easy to use for blended learning purposes by course tutors, it will promote a favourable attitude towards the technology and otherwise. The effect of effort expectancy of technology on the attitude towards the said technology is evident in studies such as that of Altanopoulou and Tselios (2017); Isaias, Reis, Coutinho and Lencastre (2017) and Thomas et al., (2013). Based on the forgoing discussion, this study postulates that: 
H2: Course tutors' effort expectancy of LMS technology has a positive relationship with their attitude towards LMS-enabled blended learning in distance education.

\section{Relationship between Facilitating Conditions and Attitude towards LMS for Blended Learning}

Venkatesh et al. (2003) defined facilitating conditions (FC) as the "degree to which an individual believes an organizational and technical infrastructure exist to support use of the system" (p. 453). The construct is defined in this study as the degree to which course tutors believe that there is the existence and availability of ICT infrastructure, technical support, institutional policy and enthusiastic leadership to support the use of LMS. In other acceptance models (TPB/DTPB, C-TAM-TPB) the construct is termed as perceived behavioural control and in IDT as compatibility (Bervell \& Umar, 2017; Venkatesh et al., 2003). The introduction of a new technology in any working atmosphere connotes some form of initial challenges in its utilization (Venkatesh, 2012). To overcome the mental instability and working frustrations, it is expected that organizations will provide the needed support (both administrative and technological) to ease the use of the system (Bervell \& Umar, 2017).

ICT infrastructure should be available and reliable while institutional policies should present tutors opportunities and incentives for use of LMS. In the area of training and support, tutors should be trained to become efficient users of the technology and sustained technical assistance provided. In terms of leadership, the head of the colleges, institutes and departments should serve as role models and channels of support for LMS usage (Macharia, 2010; Mtebe, 2016). Thus, the environment made conducive in the wake of a new technology (in this instance LMS) has an effect on the individuals' perceived ease of use or effort expectancy which ultimately influences their attitude towards LMS usage (Bervell \& Umar, 2018). In effect, facilitating conditions taps the fit between the individual and the ease with which an LMS can be applied. The effect of facilitating conditions on attitude towards technology offers a direct predictive ability on attitude towards (LMS) use (Bervell \& Umar, 2016; Davis, 1981; Thomas et al., 2013). This makes the construct a crucial element of concern in LMS acceptance research especially in developing countries where conditions for LMS use may not be at optimum levels (Bervell \& Umar, 2017; Mtebe, 2016, Omoregbo et al., 2017). Authors such as Altanopoulou and Tselios (2017), Kumi, Reychav and Sabherwal (2012), and Thomas et al. (2013) have indicated the positive relationship between facilitating conditions and attitude towards e-learning technologies. In effect, this study hypothesizes that:

H3: Course tutors' view of facilitating conditions of LMS technology use has a positive relationship with their attitude towards LMS-enabled blended learning in distance education.

\section{Relationship between Social Influence and Attitude towards LMS for Blended Learning}

Social influence defines the effect or influences that other people who are seen to be of importance have on the decision of potential adopters to accept a new technology (Bervell \& Umar, 2017). Venkatesh, Thong and $\mathrm{Xu}(2012)$ explained social influence as the extent to which "consumers perceive that important others (e.g. family, friends, etc.) believe they should use a particular technology" (p. 159). In education, if tutors believe that their influential acquaintances prefer them to use an LMS to augment and complement their face-toface instruction; they will have the positive attitude towards it and vice versa. The construct of social influence is captured in TAM2/TRA/TPB/DTPB/C-TAM-TPB as subjective norm, in MPCU as social factors and IDT as image (Bervell \& Umar, 2017; Venkatesh et al., 2003). The impact of these referenced relevant others influences individuals' affection towards a new system (LMS).

Implementing blended learning cannot be simplified and limited to technological factors, rather a complex mash up of varied factors in the social and behavioural context (Tarhini, Hone, \& Liu, 2013). Since individuals are the end users of a system, the influence of the social milieu is worth considering. In the words of Taiwo and Downe (2012),

"besides an effective and easy to use information system, end-users might not be obliged to use the system until they are motivated by important others (people) that can influence their attitude and behaviour. With the way people's life are moulded around 
role models, public figures, sportsmen and celebrities, an encouragement by such important Figures to use the system can motivate users to accept the use of an information system" (p. 54. as cited in Taiwo, Downe, \& Mahmood, 2013).

Shahadat, Mahbub and Che (2012) are of the view that there is a dearth of knowledge concerning the key role of such factors in the acceptance and use of technology, especially in the developing countries. Favourable influence of referent others of course tutors towards LMS will positively shape up the attitudes of course tutors towards the use of LMS for blended learning in distance education. Recent research from Ursavas and Bakir (2019), Nassuora (2012), and Teo (2009) confirm the relationship existing between the two constructs in terms of technology acceptance although Altanopoulou and Tselios (2017) found contrasting evidence. Consequently, this study proposes that:

H4: Social influence on course tutors LMS use has a positive relationship with their attitude towards LMS for blended learning in distance education.

\section{Mediating Role of Attitude on Performance Expectancy, Effort Expectancy, Facilitating Conditions and Social Influence towards LMS-Enabled Blended learning}

Subsequent to the addition of personality factors in the UTAUT model and accordingly, their effectiveness in determining behavioural intentions in technology acceptance research within higher education, the efforts by some rather not many researchers, was to extend the effect of prediction of these variables to verify for indirect effects on the conventional exogeneous factors of UTAUT, especially in situations where the direct effects of personality factors on behavioural intentions were strongly significant. These attempts provide an important threshold by further broadening the possibilities of testing and validating these variables in technology acceptance research, to offer a clearer understanding of their complex interrelationships. For instance, through regression analysis, authors such as Nassuora (2012), El-Gayar et al. (2011), and Thomas et al. (2013) attempted to test for the indirect effects of UTAUT latent variables (performance expectancy, effort expectancy, social influence and facilitating conditions) on some personality factors. For example, Thomas et al. (2013), and Nassuora (2012) modelled the indirect effect by all four key constructs (performance expectancy, effort expectancy, social influence and facilitating conditions) of the UTAUT model on attitude towards behavioural intention while El-Gayar et al. (2011) focused only on the indirect effect of effort expectancy and performance expectancy on attitude towards behavioural intention.

However, the proof of mediating effect cannot be verified by just regressing the UTAUT exogeneous factors (performance expectancy, effort expectancy, social influence and facilitating conditions) on the personality variable attitude. According to Hair, Hult, Tomas, Ringle, and Sarstedt, (2013) and Preacher and Hayes (2008), there should be a bootstrap of the indirect effect to statistically confirm significance of full mediation. This study goes a step further to argue that when such indirect relationships are established, then the UTAUT exogeneous variables (performance expectancy, effort expectancy, social influence and facilitating conditions) should be tested for mediation through attitude to verify for significance. The reciprocal effects between these two categories of variables are emphasized by Bandura (1986). He contends that the effect of environmental factors, personality factors (cognitive and affective) and behaviour are reciprocal and that individual successful manipulation of technology influences their cognitive perceptions as well (Bervell \& Umar, 2016).

For instance, the indirect effects of Perceived Usefulness (performance expectancy in UTAUT) and Perceived Ease of Use (effort expectancy in UTAUT) on behavioural intention through attitude, is proposed by Davies, Bargozzi, and Warshaw (1989) in TAM 1 and Davis and Wong (2007) in TAM 2 and even in SCT-IT framework. For individual innovators, they possess strong and positive attitudes towards new phenomena. Rogers (1962) indicated that innovators are risk takers and audacious without circumspection. Their unperturbed nature when confronted by resultant failure in trying out new technology is often compensated by a self encouragement of trying out a new technology to satisfy their curiosity (Bervell \& Umar, 2016). The reverse is the case when participants are laggards and possess unfavourable attitudes. In a situation as this, the effects of PE, EE, SI and FC do not influence them directly (van Raaij \& Schepers, 2008) in attempting the utilization of a new technology. A single result by Teo (2010) indicated a mediating effect of attitude on the 
technology use factors of facilitating conditions and social influence. Recent studies from Isaias, Reis, Coutinho and Lencastre (2017) who regressed the four constructs (performance expectancy, effort expectancy, social influence and facilitating condition) on attitude towards empathic technologies for distance and mobile learning also failed to test for possible mediation. This is insufficient to confirm the mediating role of attitude on the above technological use factors, hence the need to further validate (Bervell \& Umar, 2016). Against this background, the study hypothesis that:

H5: Course tutors' attitude towards LMS for blended learning in distance education mediates their performance expectancy towards LMS-enabled blended learning.

H6: Course tutors' attitude towards LMS for blended learning in distance education mediates their effort expectancy towards LMS-enabled blended learning.

H7: Course tutors' attitude towards LMS for blended learning in distance education mediates their facilitating conditions towards LMS-enabled blended learning.

H8: Course tutors' attitude towards LMS for blended learning in distance education mediates their social influence towards LMS-enabled blended learning.

\section{Relationship between Attitude and Behavioural Intention towards LMS-enabled Blended Learning}

Attitude has been defined as an evaluative judgement either favourable or unfavourable, that an individual possesses and directs towards an object (Elias, Smith, \& Burney, 2012; Kohnke, Cole, \& Bush, 2014). From his viewpoint, Hurst (2010) explains attitude toward usage of technology as an individual's overall affective reaction towards using a system (Venkatesh, et al., 2003). Related to this study, attitude refers to tutors' overall behavioural reaction (emotionally based) to accept LMS technology for blended learning in distance education. Gasaymeh (2009), and Mtebe (2016) agree with Ajzen and Fishbein (1980) who stated that "to predict a single behaviour, we have to assess the person's attitude towards the behaviour and not his attitude towards the target at which the behaviour is directed" (p. 27). Fisbein reiterates that attitude can predict behaviours either positively or adversely. In view of this, the trait attitude becomes a litmus test in the determinant of the behaviour before a final judgement on the performance of the actual behaviour.

For instance, faculty members' attitude towards the introduction of internet-based distance education represented a major predictor of a successful and sustained implementation (Gasaymeh, 2009). Hence the intention to perform behaviour is a function of the attitude (positive or negative) towards that particular behaviour. According to Kohnke, Cole, and Bush (2014), attitude towards technology has proven to be a strong predictor of behavioural intention and has received substantial empirical support (Pavlon \& Fygenson, 2006). This is supported by Mtebe, Mbwilo, and Kissaka (2016) who stated that, a number of studies have indicated that teachers' attitude towards technology directly influences their acceptance and integration of such technologies in their pedagogical practices. This assertion is supported by Mbengo (2014) who opined that attitude directly and significantly influence the behavioural intention to use e-learning systems. In an empirical study by Mbengo (2014) on university lecturers' intention to accept e-learning systems, the findings indicated that attitude had a strong and positive influence on behavioural intention in determining the acceptance of e-learning system use in Zimbabwe. This was further confirmed by Bervell and Umar (2017), and Adjin-Tetteh (2014) in Ghana, Oye et al. (2014) in Nigeria, and Yamim, Ishak, and Ibrahim (2014) in Malaysia as well as El-Gayar and Moran (2016). In view of the above, this study hypothesizes that:

H9: Course tutors attitude towards LMS determines their behavioural intention towards LMS-enabled blended learning.

Based on the above developed hypotheses with relation to the literature, a conceptual model was developed. This is illustrated by Figure 2. 


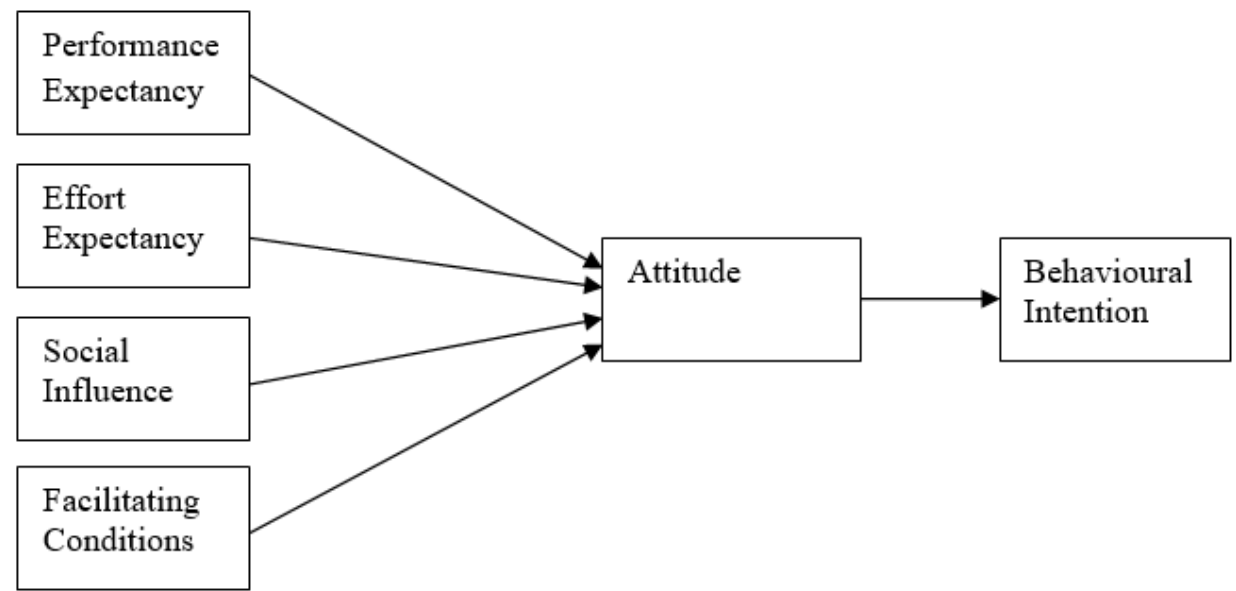

Figure 2. Conceptual Model Based on the TR-SR-TF (Bervell \& Umar, 2018)

\section{MATERIALS AND METHODS}

The study adopted the quantitative approach based on a Partial Least Squares Structural Equation Modelling (PLS-SEM) technique. It employed the survey design to collect data from a representative sample of 267 course tutors across distance education centres within Ghana with the questionnaire as the instrument for data collection. The representative sample of 267 was drawn out of a population of 400 course tutors who participated in a piloting of Learning Management System for distance education delivery project. The final 267 questionnaires retrieved after distribution to the total population of 400 course tutors were adequate for the data analysis based on Krejcie and Morgan (1971) criteria with 95\% confidence a 5\% margin of error. The representative sample was also justified by Green (1991) estimation for sampling adequacy for latent variables in survey-based studies. Additionally, the questionnaire comprised of three sections: the first section focused on demographic data (age, gender, face-to-face experience, course taught and location while the second section elicited responses on the exogeneous variables (performance expectancy, effort expectancy, social influence and facilitating conditions); with the third involving the endogeneous variables (attitude and behavioural intention) respectively. The items within the survey instrument were generated and modified from Venkatesh et al. (2003), Davis (1989), and Venkatesh and Bala (2008) of the UTAUT, TAM and TAM 3 respectively. Following this, an exploratory and confirmatory factor analyses were run in PLS-SEM to delete the factors that loaded below the 0.5 threshold as recommended by Hair et al. $(2015,2017)$, and Kline (2015). The final items of 27 across the six constructs were used for the path analyses.

\section{ANALYSIS AND FINDINGS}

\section{Demographic Data}

Respondents' profile information comprised gender, age, face-to-face experience, course taught, and location of study centre. Gender distribution shows a majority for males with a frequency of 164, representing $61.4 \%$ as against that of female tutors ( $n=103$ or $38.6 \%$ ). Age differentials between the groupings had most of the tutors falling within the $36-45$ range, representing $38.2 \%$ of the total sample distribution. This was followed by those who were up to 35 years ( $n=67$ or $25.1 \%$ ) with not much difference from the 46-55 category with a tally of 64 (24.0\%). The least representation was those with ages above 55. In terms of experience with face-to-face mode of instruction, a majority of the course tutors numbering 112 were conversant with this mode for about six to ten years with a corresponding percentage of $42 \%$. A total number of 98 tutors rather had this experience for close to 5 years representing $36.7 \%$. A less majority ( $n=57$ or $21.3 \%$ ) of the tutors had face-to-face experience above of 10 years. In this study sample, the education tutors were more than the other two programme categories. They were 136 accounting for half $(50.9 \%)$ of the total study sample. This was followed by the business group and subsequently the maths and science group with $25.8 \%$ and $23.2 \%$ respectively. Location of centres was more concentrated in the urban and semi urban areas. These two categories constituted 100 and 73 each respectively in terms of frequency 
representing $37.5 \%$ and $23.7 \%$. The least categories were the study centres at the semi-rural and rural settings. Together, they constituted $31.2 \%$. This is very representative of the general study centre location distributions within the country.

\section{Model Analysis}

The initial assessment of the measurement model was determined through Partial Least Squares algorithm for confirmatory factor analysis. The next criteria for measurement model comprised the Cronbach's Alpha, rho_A composite reliability and average variance extracted as recommended by Hair et al. (2017), and Kline (2015). Results of the measurement model are indicated by Figure 3 and Table 1.

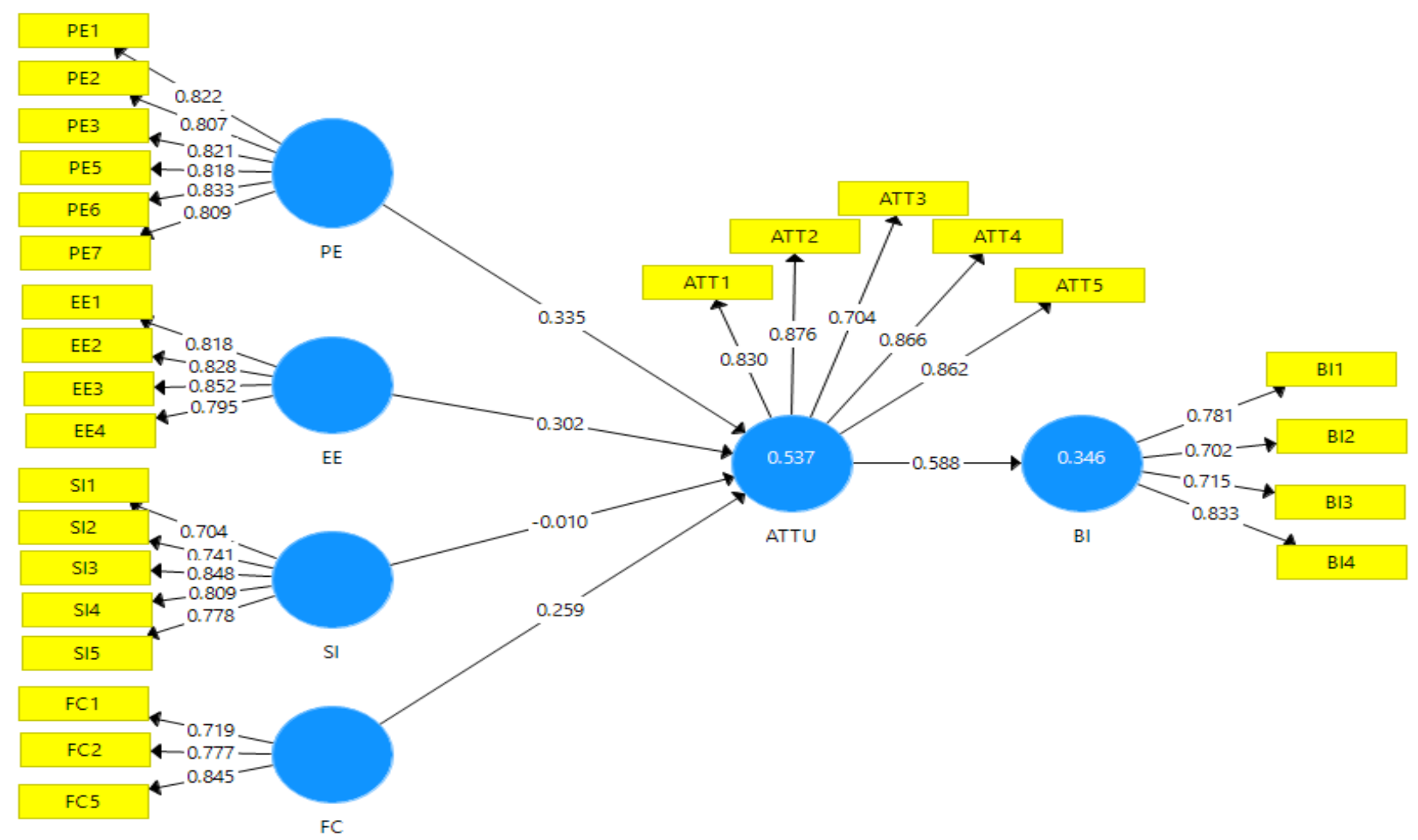

Figure 3. PLS Algorithm for Confirmatory Factor Analysis

Table 1. Reliability and Validity

\begin{tabular}{lcccc}
\hline Constructs & Cronbach's Alpha & rho_A & Composite Reliability & Average Variance Extracted (AVE) \\
\hline ATTU & 0.885 & 0.891 & 0.917 & 0.689 \\
BI & 0.754 & 0.762 & 0.844 & 0.577 \\
EE & 0.842 & 0.850 & 0.894 & 0.678 \\
FC & 0.702 & 0.732 & 0.825 & 0.612 \\
PE & 0.902 & 0.906 & 0.924 & 0.670 \\
SI & 0.840 & 0.857 & 0.884 & 0.605 \\
\hline
\end{tabular}

From Figure 3, all the loadings for the items across the constructs were higher than the 0.7 threshold and confirmed the adequacy of all the items in defining the constructs they measured (Hair et al., 2017; Kline, 2015; Nunnally \& Bernstein, 1994).

From Table 1, the Cronbach's Alpha values for all the constructs were between 0.702 and 0.902. Rho_A had values within the range of 0.732 to 0.906 . For composite reliability which is more reliable than the Cronbach's Alpha had values between 0.825 and 0.924 . The above value ranges were all above the threshold of 0.702 . According to Hair et al. (2017), Kline (2015), and Nunnally (1994), values of 0.702 and higher for all the indicators of reliability above indicate a good internal consistency of the measurement model. Average variance extracted values of 0.5 and above indicates a good internal consistency measure. (Hair et al., 2017; Kline, 2015; Nunnally, 1994). The above value range of between 0.577 and 0.689 meets the threshold of internal consistency. The overall reliability of the instrument was a Cronbach's alpha of 0.815 which is the 
average of all the constructs' Alpha coefficients indicates a good instrument for the measurement model (Cronbach, 1990; Field, 2013; Hair et al., 2015).

\section{Discriminant Validity}

Discriminant validity defines the distinctiveness of each variable in the measurement model (Hair et al., 2017; Henseler et al., 2016). This means that each variable in the model should distinctively measure a construct differently from all the other constructs (Hair et al., 2017; Henseler et al., 2016; Kline, 2015). To determine the discriminant validity, the Heterotrait-Monotrait Ratio (HTMT) strict measure is recommended by Henseler et al. (2016), and Hair et al. (2017). The results of HTMT for the model is shown in Table 2.

Table 2. HTMT Results

\begin{tabular}{lcccccc}
\hline Constructs & ATTU & BI & EE & FC & PE & SI \\
\hline ATTU & $\mathbf{0}$ & & & & & \\
BI & 0.716 & $\mathbf{0}$ & & & & \\
EE & 0.724 & 0.595 & $\mathbf{0}$ & & & \\
FC & 0.653 & 0.599 & 0.564 & $\mathbf{0}$ & $\mathbf{0}$ & \\
PE & 0.702 & 0.507 & 0.735 & 0.506 & 0.402 & $\mathbf{0}$ \\
SI & 0.388 & 0.289 & 0.476 & 0.575 & \\
\hline
\end{tabular}

\section{Heterotrait-Monotrait Ratio (HTMT)}

From Table 2, all diagonal loadings on the same construct is zero and their corresponding loadings between two different constructs were less than the 0.85 recommended threshold (Hair et al., 2017; Henseler et al., 2016). The results indicate that the constructs in the measurement model measured distinctly from all other constructs. Hence no constructs redundancy in the model.

\section{Collinearity}

The presence of collinearity in measurement models adversely affects the reliability of the significance of path analysis for variable prediction (Bervell \& Arkorful, 2020; Field, 2013; Kock \& Lynn, 2012). In order to detect for multicollinearity, Kock (2016) and Hair et al., (2017) recommended the test of the variance inflation factors (VIF) for reflective models (Bervell \& Arkorful, 2020; Bervell \& Umar, 2018). Results of the VIF analysis are presented in Table $\mathbf{3}$.

Table 3. Collinearity Statistics

\begin{tabular}{lccccc}
\hline Constructs & ATTU & BI & EE & FC & PE \\
\hline ATTU & & 1.000 & & & \\
BI & & & & \\
EE & 1.875 & & & \\
FC & 1.442 & & & \\
PE & 1.785 & & & \\
SI & 1.357 & & & \\
\hline
\end{tabular}

From Table 3, all the VIF values are less than the 3.3 strict criterion as recommended by Kock (2016) and Hair et al. (2017). This is because the VIF values ranged between 1.000 and 1.875 . The results are indicative of a multicollinearity free model.

\section{Structural Model Analysis}

The second stage of assessing the model of this study is the structural model analysis. This is to verify for the significance of the hypothesized predictive relationships of the exogeneous variables in the model (Bervell \& Umar, 2018; Hair et al., 2017; Kline, 2015). In order to assess the paths relationships, the 5000 samples bootstrapping sequence in PLS-SEM was run as recommended by Hair et al. (2015, 2017), and Kline (2015). The results of the paths analysis are indicated graphically by Figure 4 and tabulated in Table 4. 


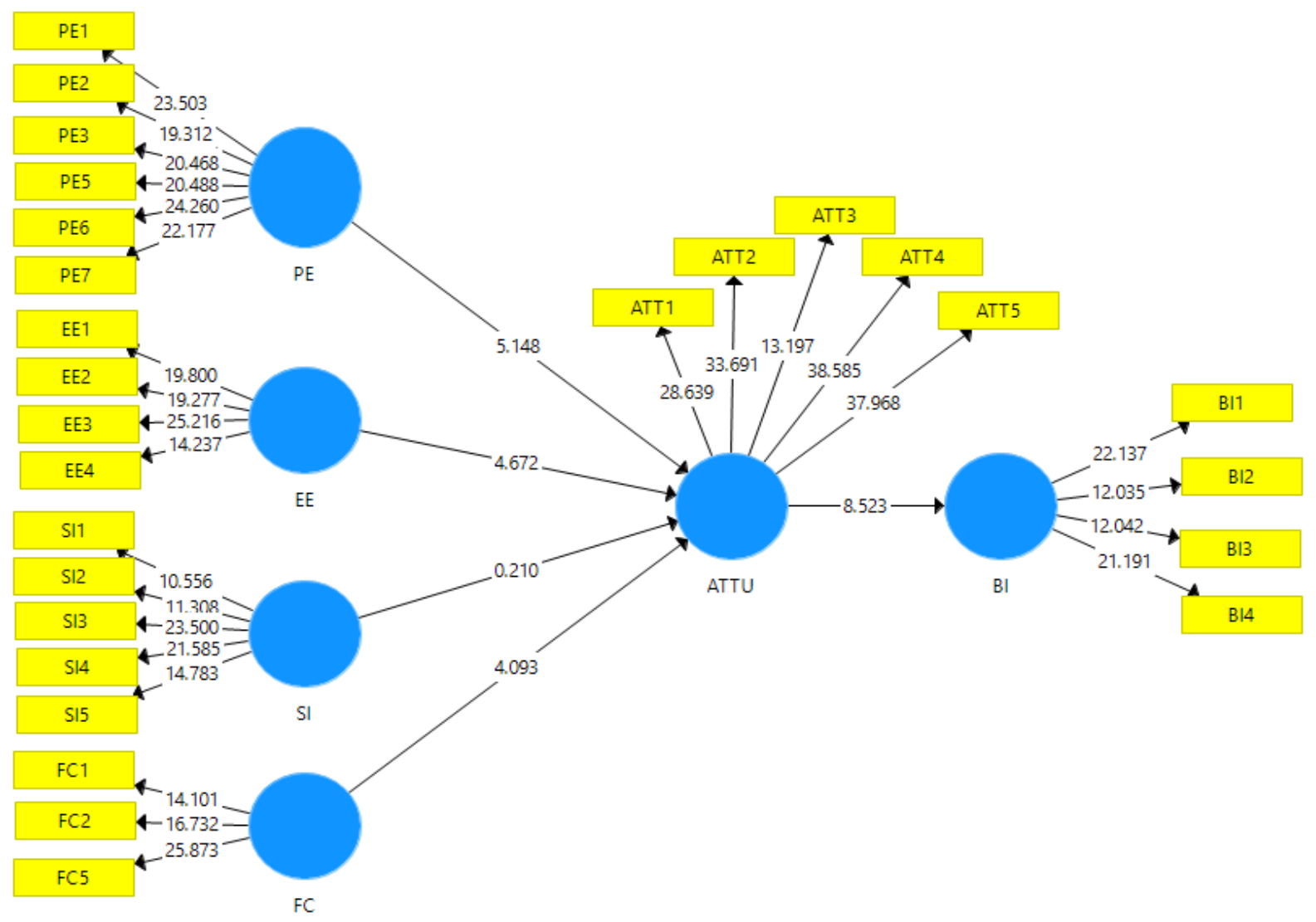

Figure 4. Bootstrap Results for Path Analysis

Table 4. Direct Path Analysis Results

\begin{tabular}{|c|c|c|c|c|c|c|c|}
\hline \multirow{2}{*}{ Relationships } & \multirow{2}{*}{ Beta-values } & \multirow{2}{*}{ Std. Error } & \multirow{2}{*}{ t-values } & \multirow{2}{*}{$p$-values } & \multirow{2}{*}{$f^{2}$} & \multicolumn{2}{|c|}{ Confidence Interval } \\
\hline & & & & & & LB & UB \\
\hline$\overline{\text { ATTU }->\mathrm{BI}}$ & 0.593 & 0.069 & 8.523 & 0.000 & 0.530 & 0.469 & 0.696 \\
\hline EE -> ATTU & 0.302 & 0.065 & 4.672 & 0.000 & 0.105 & 0.187 & 0.400 \\
\hline FC -> ATTU & 0.259 & 0.063 & 4.093 & 0.000 & 0.101 & 0.154 & 0.366 \\
\hline PE -> ATTU & 0.340 & 0.065 & 5.148 & 0.000 & 0.136 & 0.237 & 0.449 \\
\hline SI -> ATTU & -0.010 & 0.045 & 0.210 & 0.417 & & -0.075 & 0.074 \\
\hline
\end{tabular}

${ }^{*} p<0.001$

From Table 4, four of the hypothesized paths in the model were significant. For instance, attitude predicted behavioural intention at $\mathrm{t}=8.523, \mathrm{p}<0.000$; performance expectancy, effort expectancy, and facilitating conditions all determined attitude at $\mathrm{t}=5.148, \mathrm{p}<0.000 ; \mathrm{t}=4.672, \mathrm{p}<0.000$ and $\mathrm{t}=4.093, \mathrm{p}<0.000$ respectively. However, social influence was not a predictor of attitude, and this is proven by a t value of 0.210 at $p=0.417$; $p>0.05$ threshold. The significance of the other paths also showed good effects sizes of values ranging between 0.101 and 0.530 (Bervell \& Umar, 2018; ; Hair et al., 2017; Kline 2015). Finally, the unidimensionality of the confidence intervals proved that the significant paths were valid based on the lower boundary and corresponding upper boundary values and defeats the element of spuriousity (Field, 2013). The directions of the predictive effects of all the predictors (performance expectancy, effort expectancy, and facilitating conditions) of attitude towards LMS-enabled blended learning to indicate a positive predictive effect (Field, 2013). This implies that as the various technological use factors improve, there is a corresponding increase in favourable attitudes towards LMS-enabled blended learning acceptance intentions by tutors in distance education. The same can be inferred by the confidence interval direction for attitude on behavioural intentions of LMS-enabled blended learning. 


\section{Mediation Analysis}

The second part of the paths analysis was the mediation paths analysis through a bootstrap of the indirect effects of attitude on performance expectancy, effort expectancy, and facilitating conditions towards behavioural intention as recommended by Hair et al. $(2015,2017)$. The results are shown in Table 5.

Table 5. Mediation Path Analysis Results

\begin{tabular}{lcccccc}
\hline Relationships & \multirow{2}{*}{ Beta-values } & Std. Error & t-values & p-values & \multicolumn{2}{c}{ Confidence Interval } \\
LB & UB \\
\hline EE -> ATTU -> BI & 0.178 & 0.044 & 4.038 & 0.000 & 0.105 & 0.250 \\
FC $->$ ATTU -> BI & 0.155 & 0.047 & 3.232 & 0.001 & 0.080 & 0.236 \\
PE $->$ ATTU -> BI & 0.201 & 0.040 & 4.926 & 0.000 & 0.139 & 0.270 \\
SI $>$ ATTU -> BI & -0.006 & 0.027 & 0.207 & 0.418 & -0.046 & 0.042 \\
\hline
\end{tabular}

$* p<0.001$

For mediation analysis of attitude on the three technological use factors towards behavioural intention for LMS-enabled blended learning, the results as shown by Table 5 indicates that attitude mediated all the three technological use factors. This is confirmed by $t=4.038, p<0.000 ; t=3.232, p<0.001$ and $t=4.926, p<0.000$ for effort expectancy, facilitating conditions and performance expectancy, respectively. This indicates that the direct predictive effects of the three factors on behavioural intention towards LMS-enabled blended learning by tutors are spurious with the existence of attitude within the model. Thus, attitude becomes a major predictor or determinant of behavioural intention while having expectancy, facilitating conditions and performance expectancy as its antecedents. The effect sizes and unidimensional nature of the mediation effects validates the mediation results.

\section{Derived Model}

Based on the results of the structural model analyses, the derived model obtained is depicted by Figure $\mathbf{5}$.

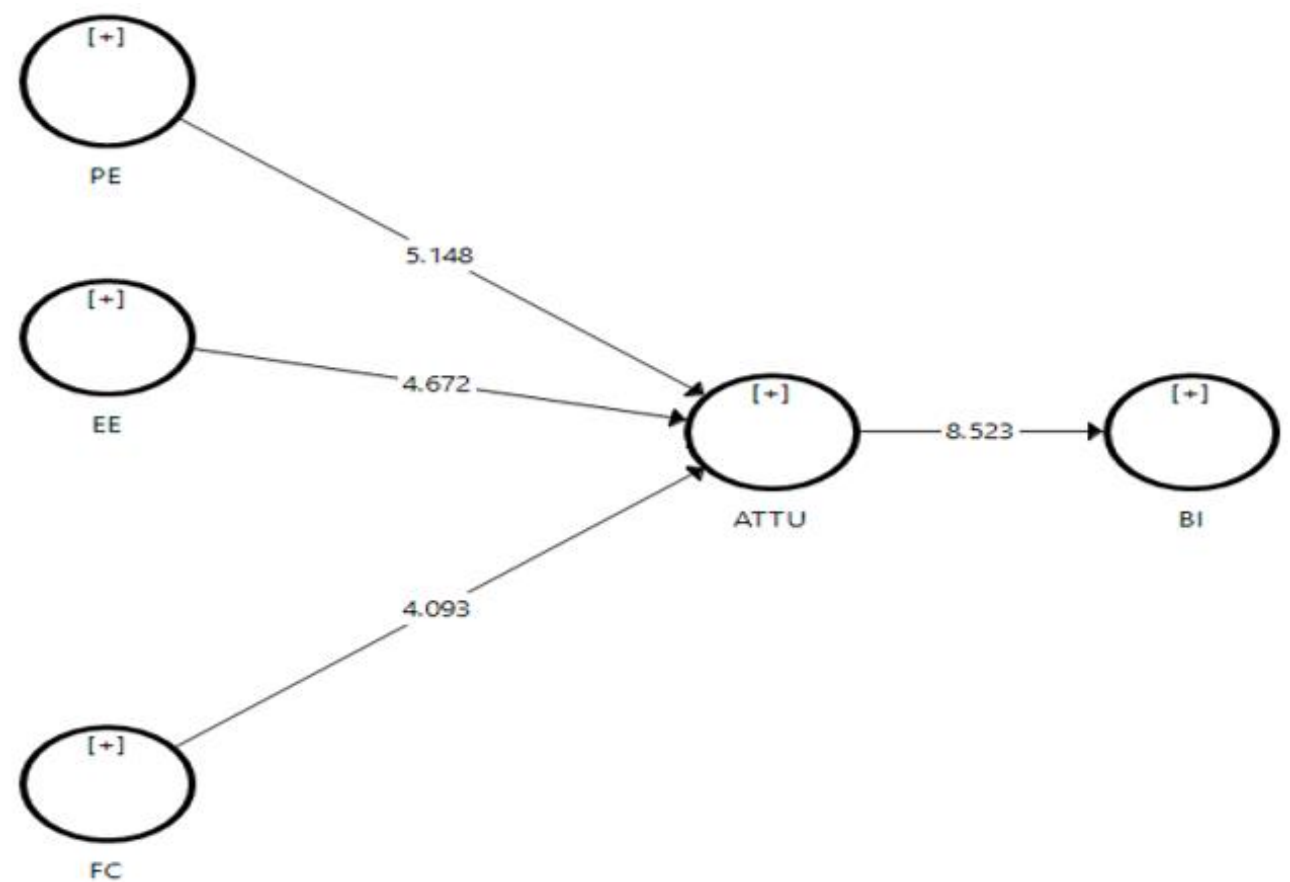

Figure 5. Derived Model

\section{Model Fit}

To assess the model fit for the study, the Standard Root Mean Residual (SRMR), rmsTheta and Normed Fit Index (NFI) for PLS-SEM were utilized in accordance with Hair et al. $(2015,2017)$ recommendation. The results of the model fit analysis are shown in Table 6. 
Table 6. Model fit values

\begin{tabular}{lc}
\hline Indices & Estimates \\
\hline SRMR & 0.069 \\
rms Theta & 0.145 \\
NFI & 0.764 \\
\hline
\end{tabular}

From Table 6 the SRMR was 0.069, rmsTheta and NFI with values of 0.145 and 0.764 respectively. Subsequently all the above indices were greater than the recommended thresholds Hair et al. (2017), and Henseler et al. (2016) and this indicate a good model fit for PLS-SEM.

\section{DISCUSSION}

This study modelled relationships of technological use factors on attitude towards behavioural intention of course tutors for LMS-enabled blended learning in distance education. Additionally, these factors were tested for mediation effects by attitude in relation to behavioural intention of tutors towards LMS-enabled blended learning.

On the predictors of attitude, performance expectancy defined course tutors' benefits derived (or perceived to be derived) from using LMS for blended learning in distance education. It has been noted that expectations gained or to be gained from system use influence acceptance behaviour (Ajzen, 1991; Venkatesh et al., 2003, 2012). However, the idea of having benefits from using LMS influences the attitude of tutors in a multidimensional direction. This is because, good performance outcome or otherwise of LMS to tutors, shape their affection (either favourable or unfavourable) towards LMS (Davis, 1989). Within this study, the variable rather had a positive and significant relationship with course tutors' attitude towards their intention behaviour. After determining system usage, individuals weigh the benefits, whether personal or job performance relatedness (Bervell \& Umar, 2017). Since job outputs as well as personal progress are two most important elements in every organization, a judgment on the viability of these elements has a consequential effect on personal outlook towards technology use. To course tutors, LMS usage was important and could help them to fulfil pedagogical or andragogical tasks but were uncertain whether it could offer them personal benefits. Irrespective of the latter uncertainty, their attitude towards acceptance was favourable and relatively high based on the notion that using the system improves or will eventually improve their teaching and learning process. Their emphasis on LMS making students understand concepts taught better was evident in their responses and thus created in them positive attitudes. The reverse would have been the case if their inclination towards LMS usage was one that was of less importance to them. The direct relationship between the two variables makes it necessary for course tutors to know and also experience direct benefits opened to them with regards to utilizing LMS to support face-to-face sessions. Although this relationship between performance expectancy and attitude is not modelled in the original UTAUT model, this study sought to verify its significance based on the relationship between perceived usefulness and attitude in the TAM model (Davis, 1989). The result satisfies the connection between these two variables within the UTAUT model as well and confirms earlier studies by Altanopoulou and Tselios (2017), Isaias, Reis, Coutinho, and Lencastre (2017), Bervell and Umar 2016), and Thomas et al. (2013).

However, the extent to which course tutors believed that other external referent others or colleagues could influence their LMS-enabled blended acceptance intentions did not have any direct effect. Course tutors believed they were independent minded and could take decisions by themselves based on personal results achieved from system usage or reflection on possible effects on their pedagogical or andragogical activities. They seemed to rely very little on colleague influence or persuasion in order to form their LMS acceptance intentions to support face-to-face session. This explanation is partially explained by the fact that the majority of the course tutors were middle aged and were matured enough to make informed decisions on their own, reminiscing possible gains attributed to the system use. The results obtained in this study contradicts with that of Ursavas (2019), and Taiwo, Downe, and Mahmood (2013) but is in tandem with a study by Altanopoulou and Tselios (2017).

Subsequently, conditions put in place to support LMS usage were considered by course tutors as necessary in forming their attitude towards LMS acceptance. This means that even if course tutors have positive 
attitudes towards LMS usage by way of expectations to be derived from usage, conditions surrounding the utilization of this system could further deepen or weaken the direction of their attitude (Bervell \& Umar, 2018). The significant and positive relationship between facilitating conditions and attitude of course tutors is indicative of the fact that, facilities and resources for LMS use made available and accessible to them, increase their already acquired positive attitude towards LMS use. Course tutors' LMS related attitude tends to be frustrated as a result of the non-accessibility of these facilities, and could gradually wane down the positive attitude of course tutors. Based on the Stimulus Response Theory (Bervell \& Umar, 2019; Mehrabian \& Rusell, 1974), the user's attitude could even be negative in the long run, if the needed resources are not available and accessible to them. In effect, the higher the sense of availability and accessibility of facilities towards system use, the more positive course tutors' attitude become in relation to LMS use intentions. This result resonates with that of Omoregbo (2018), Mtebe (2016), and Kumi, Reychav, and Sabherwal (2012).

Additionally, the manipulation of LMS to offer the blended mode demands some effort to be exerted by course tutors towards its actual use. The effort required for LMS usage as a complementary element to blended learning was relevant to course tutors in determining their intentions towards acceptance. The relationship between effort expectancy and intention towards LMS usage was significant within this study. Course tutors factored in the ability needed by them to operate the system to be able to engage in LMS enabled-blended learning as very important if they accept the system for such purpose. The more they perceived the amount of effort required of them to operate LMS, the lesser their intention decision will be (Bervell \& Umar, 2018). On the other hand, having the impression that the system was easy to use commensurate in higher acceptance decisions. Attuquayefio and Addo (2014) emphasized that the easiness or otherwise of a system is a vital component of influence on novel users' intention formation, especially at the earlier stages of usage. System functionalities are expected by new users to be relatively easier to use to perform the intended task (Ghazal et al., 2018). This promotes positive and higher intentions on the part of users. Within this study, course tutors reckoned that the system was relatively not too easy to use and that they envisaged little difficulty in using it for blended learning. They however had the impression that with time, they could master its usage. Similar positive predictive relationship between effort expectancy and attitude was reported by Altanopoulou and Tselios (2017), Isaias, Reis, Coutinho, and Lencastre (2017) as well as Thomas et al. (2013).

For mediation, attitude mediated the direct effect of tutors' performance expectancy on behavioural intention towards LMS-enabled blended learning. This is due to the fact that, the effect of course tutors' performance expectancy on intention was totally absorbed by that of LMS related attitude. This means that, course tutors' attitude towards LMS fully mediated the effect of their performance expectancy. Course tutors' performance expectancy did not predict intention behaviour but its effect was indirectly through their attitude towards LMS. This pseudo effect is in variance with the theorization of the UTAUT model by Venkatesh et al. (2003) who rather indicated a reversal of the relationship. However, the result obtained within this study has been theorized in the TAM model by Davis (1986) and used in most studies that employed TAM or include attitude in the UTAUT model although has not been tested forthwith in the literature. The significance of the full mediating effect of LMS related attitude on performance expectancy obtained in this study provides a contrasting view on the direct effect of performance expectancy on behavioural intention (Venkatesh et al., 2003; Venkatesh, Thong and Xu but confirms earlier postulations by Bervell and Umar (2016) and empirically by Thomas et al. (2013), and El-Gayer et al. (2011).

The mediation relationship between effort expectancy and attitude was also significant such that the direct effect of effort expectancy on tutors' behavioural intention towards LMS-enabled blended learning was fully mediated by the construct attitude. This implies that the effort expectancy of tutors was largely a determinant of their attitude towards LMS and not directly a predictor of their intentions towards the technology for blended learning purposes. In this vein, effort expectancy of tutors was only a precursor to their attitude formations towards LMS-enabled blended learning use intentions. Consequently, effort expectancy merely defined how favourable or unfavourable their affective tendencies will be towards LMSenabled blended learning intentions for distance education delivery and no their overall behavioral intention 
of LMS-enabled blended learning uptake. This finding empirically supports earlier stance by authors such as Bervell and Umar (2016), Nassoura (2013), and Isaias, Reis, Coutinho, and Lencastre (2017).

Finally, the study found another mediating effect of attitude on the direct effect of facilitating conditions towards intentions. Direct effect of facilitating conditions on intention was only possible when the attitude factor is eliminated from the model. This means that part of the actual full effect of facilitating conditions on behavioural intention was taken over by attitude. In effect, facilitating conditions do not directly predict course tutors' intention, but rather have a greater influence on their attitude which in turn strongly determines their intention to accept LMS. This finding is in contradiction to the postulation by Venkatesh et al. (2003) but resonates with Bervell and Umar (2016), Davis (1989), and Teo (2010).

\section{Implications for Theory}

1. For theorization, the results of this study indicate that performance expectancy, effort expectancy and facilitating conditions are rather determinants of attitude in terms of technology uptake intentions. This is in line with the earlier postulations in the TAM but strongly contradicts that of the UTAUT model.

2. The results obtained also defeat the idea of spuriousity of effect of the attitude variable as postulated by the UTAUT model.

3. The significance of the mediation effects of attitude on performance expectancy, effort expectancy and facilitating conditions make attitude an important determinant of behavioural intention for technology (LMS) uptake.

\section{Implications for Practice}

1. The results imply that prior to LMS-enabled blended learning utilization in distance education delivery; tutors should be well-informed on the usefulness in terms of performance of the system and be demonstrated well to them for positive convictional dispositions.

2. The fears of extreme efforts required to use LMS to support face-to-face sessions could be allayed if proper practical sessions are held for them on how to use LMS-enabled blended learning. Again, interactive manuals can be prepared for them to ease their effort on becoming skilful on how to use LMS for distance education delivery.

3. The environment of use of LMS for blended learning by way of enabling conditions should be in place to motivate tutors. For instance ready assistance, good internet facility, quality of the system, and other motivational packages such as points for key performance indicators for LMS use tied to promotion etc.

The above recommendations for practice are consequential as they are tantamount to the formation of positive attitudinal dispositions towards the intention behaviours of tutors in using LMS for distance education delivery.

\section{Limitations of the Study}

1. The total variance explained by the predictors of attitude within the model was $53.7 \%$ leaving almost half of unexplained variance in attitude towards LMS-enabled blended learning.

2. The responses for this study were obtained from only tutors' perspectives and so cannot be generalized to all stakeholders (e.g. students) in distance education.

3. This study was limited to the distance education milieu and not the conventional university system and so the responses from distance tutors may differ from that of mainstream university lecturers who are in one location only. 


\section{Recommendations for future studies}

1. It is recommended that future studies add other variables to the model to make up for the unexplained variance in attitude towards LMS-enabled blended learning.

2. Future studies could solicit views from distance education students as well and conduct a comparative analysis from both perspectives.

3. Additional study is required with a focus on mainstream university lecturers who are also practicing blended learning to verify the universality of the results.

\section{CONCLUSION}

This study pioneered an effort to model the technological, societal and environmental dimensions of technology use on attitude of tutors towards LMS uptake for distance education delivery. It also sought to empirically test for the mediation effect of attitude on the three factors towards behavioural intentions of tutors to engage with LMS for andragogical purposes in distance education. The results were evident that within the sample of this study, performance expectancy, effort expectancy and facilitating conditions were determinants of tutors' attitude towards LMS-enabled blended learning intentions. Additionally, the mediation effects of attitude on the three factors (performance expectancy, effort expectancy and facilitating conditions) were significant towards behavioural intentions for LMS use. The results were consequential in determining the theorization and practical implications of LMS-enabled blended learning use intentions by tutors to deliver distance education.

\section{REFERENCES}

Ajzen, I., \& Fishbein, M. (1980). Understanding attitudes and predicting social behaviour. Englewood Cliffs, NJ: Prentice Hall.

Alharbi, S., \& Drew, S. (2014). Using the technology acceptance model in understanding academics' behavioural intention to use learning management systems. International Journal of Advanced Computer Science and Applications (IJACSA), 5(1). https://doi.org/10.14569/IJACSA.2014.050120

Aljaloud, M. (2012). Barriers to implementing Learning Management Systems in Saudi Arabian higher education (Unpublished Master's Thesis), Flinders University.

Altanopoulou, P., \& Tselios, N. (2017). Assessing acceptance toward wiki technology in the context of higher education. International Review of Research in Open and Distributed Learning: IRRODL, 18(6), 127-149. https://doi.org/10.19173/irrodl.v18i6.2995

Anderson, T., \& Dron, J. (2010). Three generations of distance education pedagogy. The International Review of Research in Open and Distributed Learning, 12(3), 80-97. https://doi.org/10.19173/irrodl.v12i3.890

Aoki, K. (2012). Generations of distance education: Technologies, pedagogies, and organizations. Procedia Social and Behavioral Sciences 55, 1183-1187. https://doi.org/10.1016/j.sbspro.2012.09.613

Asiri, M. J. S., Mahmud, R., Bakar, K. A., \& Ayub, F. M. A. (2012). Factors influencing the use of Learning Management System in Saudi Arabian higher education: A theoretical framework'. Higher Education Studies, 2(2), 125-137. https://doi.org/10.5539/hes.v2n2p125

Bandura, A. (1986). Social foundations of thought and action. NJ: Englewood Cliffs.

Bervell, B., \& Arkorful, V. (2020). LMS-Enabled blended learning utilization in distance tertiary education: establishing the relationships among facilitating conditions, voluntariness of use and use behaviour. International Journal of Educational Technology in Higher Education (IJETHE). https://doi.org/10.1186/s41239-020-0183-9 
Bervell, B., \& Umar, I. N. (2016). 'Mediators', 'The Mediated' or 'Predictors': Re-Conceptualizing the Tripartite Role of Personality Factors in Higher Education Technology Acceptance. Proceedings from the $16^{\text {th }}$ Annual Conference of the South East Asian Association of Institutional Research (SEAAIR), Suan Dusit University, Thailand, $21^{\text {st }}-23^{\text {rd }}$ September, 2016 (pp. 399-415).

Bervell, B., \& Umar, I. N. (2017). Validation of the UTAUT model: Re-considering non-linear relationships of Exogeneous variables in higher education technology acceptance research. Eurasia Journal of Mathematics, Science and Technology Education, 13(10), 6471-6490. https://doi.org/10.12973/ejmste/78076

Bervell, B., \& Umar, I. N. (2018). Utilization decision towards LMS for blended learning in distance education: Modeling the effects of personality factors in exclusivity. Knowledge Management \& E-Learning: An International Journal, 10(3), 309-333. https://doi.org/10.34105/j.kmel.2018.10.018

Bervell, B., Umar, I. N., \& Kamilin, M. H. (2019). Towards a model for online learning satisfaction (MOLS): reconsidering non-linear relationships among personal innovativeness and modes of online interaction. Open Learning: The Journal of Open, Distance and e-Learning, 1-24. https://doi.org/10.1080/02680513.2019.1662776

Bousbahi, F., \& Alrazgan, M.S. (2015). Investigating IT faculty resistance to Learning Management System adoption using latent variables in an Acceptance Technology Model. The Scientific World Journal, 2015 (375651), 1-11. https://doi.org/10.1155/2015/375651

Burns (2011). Distance Education for Teacher Training: Modes, Models, and Methods. Education Development Center, Inc. Washington, DC.

Chen, H. R., \& Huang, J. G. (2012). Exploring learner attitudes toward web-based recommendation learning service system for interdisciplinary applications. Educational Technology \& Society, 15(2), 89-100. Retrieved from https://www.jstor.org/stable/10.2307/jeductechsoci.15.2.89

Cronbach, L. J. (1990). Essentials of psychological testing. (5th.ed.), New York: Harper \& Row.

Davis, F. D. (1989). Perceived usefulness, perceived ease of use, and user acceptance of information technology. MIS Quarterly, 13(3), 319-340. https://doi.org/10.2307/249008

Davis, F. D., Bagozzi, R., \& Warsawa, P. R. (1992). Extrinsic and intrinsic motivation to use computers in the workplace. Journal of Applied Social Psychology, 22(14), 1111. https://doi.org/10.1111/j.15591816.1992.tb00945.x

Davis, R., \& Wong, D. (2007). Conceptualizing and measuring the optimal experience of the eLearning environment. Decision Sciences Journal of Innovative Education, 5(1), 97-126. https://doi.org/10.1111/j.1540-4609.2007.00129.x

Deperlioglu, O, Sarpkaya, Y \& Ergun, E. (2011). Development of a relational database for Learning Management Systems. The Turkish Online Journal of Educational Technology (TOJET), 10(4), 107-120. https://www.learntechlib.org/p/53329/

El-Gayar, O. F. \& Moran, M. (2016). College students' acceptance of tablet Pcs: An application of the UTAUT model. Dakota State University, 820, 2845-2850. Retrieved from https://www.researchgate.net

El-Gayar, O., Moran, M., \& Hawkes, M. (2011). Students' acceptance of tablet PCs and implications for educational institutions. Journal of Educational Technology \& Society, 14(2), 58. Retrieved from https://drive.google.com/file/d/1GEjH_1kIUig|XDKCnQq1JOXhYCNp_1V/view

Elias, S. M., Smith, W. L., \& Barney, C. E. (2012). Age as a moderator of attitude towards technology in the workplace: Work motivation and overall job satisfaction. Behaviour \& Information Technology, 31(5), 453-467. https://doi.org/10.1080/0144929X.2010.513419 
Essel, R., \& Owusu-Boateng, W. (2011). Access and Success in Learning: Technologies for Scaling Up Open and Distance Learning Programme in the Institute of Distance Learning, KNUST, Kumasi, Ghana. USChina Education Review (B 3), 423-429. http://hdl.handle.Net/11599/2230

Field, A. (2013). Discovering statistics using SPSS (4th ed.). London: SAGE.

Fishbein, M., \& Ajzen, I. (1975). Belief, Attitude, Intention, and Behavior: An Introduction to Theory and Research. Reading,MA:Addison-Wesley. Retrievedfrom http://people.umass.edu/ajzen/f\&a1975.html

Gasaymeh, A. (2009). A study of faculty attitudes toward internet-based distance education: A survey of two Jordanian public universities (PhD Thesis), the College of Education, Ohio University, Ohio, USA.

Ghazal, S., Aldowah, H., Umar, I., \& Bervell, B. (2018). Acceptance and satisfaction of learning management system enabled blended learning based on a modified DeLone-McLean information system success model. International Journal of Information Technology Project Management (IJITPM), 9(3), 52-71. https://doi.org/10.4018/IJITPM.2018070104

Green, S. B. (1991). How many subjects does it take to do a regression analysis? Multivariate behavioral research, 26(3), 499-510. https://doi.org/10.1207/s15327906mbr2603_7

Hair, J. F., Hult, G. T. M., Ringle, C. M., \& Sarstedt, M. (2017). A Primer on Partial Least Squares Structural Equation Modeling (2nd ed.). Thousand Oaks: Sage. https://doi.org/10.15358/9783800653614

Hair, J. F., Hult, G. T. M., Ringle, C. M., Sarstedt, M. (2015). A primer on partial least squares structural equation modeling (PLS-SEM). California: SAGE Publications, Inc.

Hair, J. F., Hult, G., Tomas, M., Ringle, C.M., \& Sarstedt, M. (2013). A primer on partial least squares structural equation modelling (PLS-SEM). Sage Publications, Incorporated.

Hastie, M., Hung, I., Chen, N., \& Kinshuk (2010). A blended synchronous learning model for educational international collaboration. Innovations in Education and Teaching International, 47(1), 9-24. https://doi.org/10.1080/14703290903525812

Henseler, J., Hubona, G., \& Ray, P. A. (2016). Using PLS path modeling in new technology research: updated guidelines. Industrial Management \& Data Systems, 116(1), 2-20. https://doi.org/10.1108/IMDS-092015-0382

Henseler, J., Ringle, C. M., \& Sarstedt, M. (2015). A new criterion for assessing discriminant validity in variance-based structural equation modeling. Journal of the Academy of Marketing Science, 43(1), 115135. https://doi.org/10.1007/s11747-014-0403-8

Horvat, A., Dobrota, M., Krsmanovic, M., \& Cudanov, M. (2015). Student perception of Moodle learning management system: A satisfaction and significance analysis. Interactive Learning Environments, 23(4), 515-527. https://doi.org/10.1080/10494820.2013.788033

Hurst, K. R. (2010). Technology Acceptance in a Mandatory Technology-Based Learning Environment (PhD Thesis, The University of West Florida, Florida, US). Retrieved from http://purl.fcla.edu/fcla/etd/WFE0000204

Isaias, P., Reis, F., Coutinho, C., \& Lencastre, J. A. (2017). Empathic technologies for distance /mobile learning: An empirical research based on the Unified Theory of acceptance and Use of Technology (UTAUT). Interactive Technology and Smart Education, 14(2), 159-180. https://doi.org/10.1108/ITSE-02-20170014

Kline, R. B. (2015). Principles and Practice of Structural Equation Modelling Methodology in the Social Sciences 4th ed. Guilford Publication: NY.

Kock, N. (2015). Common method bias in PLS-SEM: A full collinearity assessment approach. International Journal of e-Collaboration (IJeC), 11(4), 1-10. https://doi.org/10.4018/ijec.2015100101 
Kock, N., \& Lynn, G. (2012). Lateral collinearity and misleading results in variance-based SEM: An illustration and recommendations. Journal of the Association for Information Systems, 13(7), 1-40. https://doi.org/10.17705/1jais.00302

Kohnke, A., Cole, M. L., \& Bush, R. G. (2014). Incorporating UTAUT predictors for understanding home care patients' and clinician's acceptance of healthcare Telemedicine equipment. Journal of Technology Management \& Innovation, 9, 29-41. https://doi.org/10.4067/S0718-27242014000200003

Krejcie, R. V., \& Morgan, D. W. (1970). Determining sample size for research activities. Educational and psychological measurement, 30(3), 607-610. https://doi.org/10.1177/001316447003000308

Kumi, R., Reychav, I., \& Sabherwal, R. (2012). The Impact of Facilitating Conditions on Anxiety, Attitude, SelfEfficacy, And Performance: Insights from an Empirical Study of iPad Adoption. In Proceedings of the AIS SIGED IAIM 2012 Conference (pp. p. 1-14).

Kuo, Y.-C., Walker, A. E., Belland, B. R., \& Schroder, K. E. (2013). A predictive study of student satisfaction in online education programs. The International Review of Research in Open and Distributed Learning, 14(1), 16-39. https://doi.org/10.19173/irrodl.v14i1.1338

Mbengo, P. (2014). E-learning adoption by lecturers in selected Zimbabwe State Universities: An application of Technology Acceptance Model. Journal of Business Administration and Education, 6(1), 2014, 15 33. Retrieved February 22, 2020 from https://infinitypress.Info/index.php/jbae/article/view/886

Mohamedbhai, G. (2011). Higher education in Africa: Facing the challenges in the 21st century. International Higher Education, 63, 20-21. https://doi.org/10.6017/ihe.2011.63.8534

Moore, J. (2014). Effects of online interaction and instructor presence on students' satisfaction and success with online undergraduate public relations courses. Journalism \& Mass Communication Educator, 69(3), 271-288. https://doi.org/10.1177/1077695814536398

Moore, M. G., \& Kearsley, G. (2004). Distance education: A systems view (2nd ed.). Belmont: Wadsworth Publishing.

Mtebe, J. S. (2015). Learning Management System success: Increasing Learning Management System usage in higher education in sub-Saharan Africa. International Journal of Education and Development using Information and Communication Technology, 11(2), 51. Retrieved February 19, 2020 from http://ijedict.dec.uwi.edu/viewarticle.php?id=2005

Mtebe, J. S., Mbwilo, B., \& Kissaka, M. M. (2016). Factors influencing teachers' use of multimedia enhanced content in secondary schools in Tanzania. International Review of Research in Open and Distributed Learning, 17(2). https://doi.org/10.19173/irrodl.v17i2.2280

Nassuora, A. B. (2013). Students' acceptance of mobile learning for higher education in Saudi Arabia. International Journal of Learning Management Systems, 1(1), 1-9. Retrieved on February 12, 2020 from http://www.naturalspublishing.com/Article.asp?ArtclD=2552

Nicholas-Omoregbe, O. S., Azeta, A. A., Chiazor, I. A., \& Omoregbe, N. (2017). Predicting the adoption of ELearning Management System: A case of selected private Universities in Nigeria. Turkish Online Journal of Distance Education-TOJDE, 18(2). https://doi.org/10.17718/tojde.306563

Ntumy-Coleman, R. K. (2011). Assessing the adoption of e-learning in Ghanaian universities: Case of some Ghanaian universities (Unpublished Master's Thesis). Sweden: Luleå University.

Nunnally, J. C., \& Bernstein, I. H. (1994). Psychometric theory (3rd ed.). New York: McGraw-Hill. 
Oye, N. D., lahad, A. N., \& Rahim, A. B. N. (2012). Acceptance and usage of ICT by university academicians using UTAUT Model: A Case Study of University of Port Harcourt, Nigeria. Journal of Emerging Trends in Computing and Information Sciences, 3(1), 2079-8407. Retrieved January 22, 2020 from http://cisjournal.org/journalofcomputing/Download_January_pdf_6.aspx

Pavlou, P. A., \& Fygenson, M. (2006). Understanding and prediction electronic commerce adoption: An extension of the theory of planned behaviour. MIS Quarterly, 30(1), 115-143. https://doi.org/10.2307/25148720

Preacher, K. J., \& Hayes, A. F. (2008). Asymptotic and resampling strategies for assessing and comparing indirect effects in multiple mediator models. Behaviour Research Methods, 40(3), 897-891. https://doi.org/10.3758/BRM.40.3.879

Rogers, E. M. (1962). Diffusion of Innovations. New York: Free Press.

Shahadat, H. K., Mahbub, H., \& Che, K. C. (2012). Barriers to the introduction of ICT into education in developing countries: The example of Bangladesh. International Journal of instruction, 5(2), 1380-1470. Retrieved January 30, 2020 from http://www.e-iji.net/volumes/318-july-2012-volume-5-number-2

Sharma, A., \& Vatta, S. (2013). Role of learning management systems in education. International Journal of Advanced Research in Computer Science and Software Engineering, 3(6), 997-1002. Retrieved February 20, 2020 from https://www.semanticscholar.org/paper/Role-of-Learning-Management-Systems-inEducation-Sharma-Vatta/3d19dc963e7 fb8ce49bb6bcc 9329aa03e22a6075

Siemens, G., Gasévić, D., \& Dawson, S. (2015). Preparing for the Digital University: A Review of the history and current state of distance, blended and online learning. Athabasca University Press. Retrieved February 15, 2020 from https://onlinelearningconsortium.org/read/preparing-for-digital-university/

Sun, P.-C., Tsai, R. J., Finger, G., Chen, Y.-Y., \& Yeh, D. (2008). What drives a successful eLearning? An empirical investigation of the critical factors influencing learner satisfaction. Computers \& Education, 50(4), 1183-1202. https://doi.org/10.1016/j.compedu.2006.11.007

Taiwo, A. A., \& Downe, A. G. (2013). The Theory of User Acceptance and Use of Technology (UTAUT): A Metaanalytic review of empirical findings. Journal of Theoretical \& Applied Information Technology, 49(1). Retrieved February 19, 2020 from http://www.jatit.org/volumes/Vol49No1/fourtyninth_volume_ 1_2013.php

Taiwo, A. A., Downe, A. G., \& Mahmood, A. K (2012). User acceptance of E-government: integrating risk and trust dimensions with UTAUT model. In proceedings at the International Conference on Computer and Information sciences. Kuala Lumpur. https://doi.org/10.1109/ICCISci.2012.6297222

Tarhini, A., Hone, K., \& Liu, X. (2013). Factors affecting students' acceptance of elearning environments in developing countries: a structural equation modeling approach. International Journal of Information and Education Technology, 3(1), 54. https://doi.org/10.7763/IJIET.2013.V3.233

Teo, T. (2009). Modelling technology acceptance in education: A study of pre-service teachers. Computers and Education, 52(1), 302-312. https://doi.org/10.1016/j.compedu.2008.08.006

Teo, T. (2010). Examining the influence of subjective norm and facilitating conditions on the intention to use technology among pre-service teachers: a structural equation modeling of an extended technology acceptance model. Asia Pacific Education Review, 11(2), 253-262. https://doi.org/10.1007/s12564009-9066-4

Thomas, T. D., Singh, L., \& Gaffar, K. (2013). The utility of the UTAUT model in explaining mobile learning adoption in higher education in Guyana. International Journal of Education and Development using Information and Communication Technology (IJEDICT), 9(3), 71-85. Retrieved on February 15, 2020 from http://ijedict.dec.uwi.edu/viewarticle.php?id=1687 
Tu, C.-H., Sujo-Montes, L., Yen, C.-J., Chan, J.-Y., \& Blocher, M. (2012). The integration of personal learning environments \& open network learning environments. Tech Trends: Linking Research and Practice to Improve Learning, 56(3), 13-19. https://doi.org/10.1007/s11528-012-0571-7

Ursavaş, Ö. F., Yalçın, Y., \& Bakır, E. (2019). The effect of subjective norms on preservice and in-service teachers' behavioural intentions to use technology: A multigroup multimodel study. British Journal of Educational Technology, 50(5), 2501-2519. https://doi.org/10.1111/bjet.12834

Van Raaij, E. M., \& Schepers, J. J. (2008). The acceptance and use of a virtual learning environment in China. Computers \& Education, 50(3), 838-852. https://doi.org/10.1016/j.compedu.2006.09.001

Venkatesh, V., \& Bala, H. (2008). Technology acceptance model 3 and a research agenda on interventions. Decision sciences, 39(2), 273-315. https://doi.org/10.1111/j.1540-5915.2008.00192.x

Venkatesh, V., Morris, G. M., Davis, B. G., \& Davis, F. D. (2003). User acceptance of information technology: Toward a unified view. MIS Quarterly, 27(3), 425-478. https://doi.org/10.2307/30036540

Venkatesh, V., Thong, J. Y., \& Xu, X. (2012). Consumer acceptance and use of information technology: extending the unified theory of acceptance and use of technology. MIS Quarterly, 36(1), 157-178. https://doi.org/10.2307/41410412

Yamin, F. M., Hussain, W., Ishak W., \& Ibrahim, A. (2014). Students' Acceptance on Document Sharing through Learning Management System. Proceedings of $6^{\text {th }}$ International Conference on Education and Information Management (ICEIM-2014). Retrieved on February 16, 2020 from www.wanhussain.com

Zimmerman, T. D. (2012). Exploring learner to content interaction as a success factor in online courses. The International Review of Research in Open and Distributed Learning, 13(4), 152-165. https://doi.org/10.19173/irrodl.v13i4.1302

Correspondence: Dr. Brandford Bervell, University of Cape Coast, Cape Coast, College of Distance Education, Maths, Science \& ICT, Ghana. E-mail: b.bervell@ucc.edu.gh 